\title{
PENGARUH PENGEMBANGAN KARIR DAN MOTIVASI KERJA TERHADAP KINERJA PENYULUH KELUARGA BERENCANA (PKB) PADA BADAN KELUARGA BERENCANA DAN PEMBERDAYAAN PEREMPUAN (BKBPP) KABUPATEN KARAWANG
}

\author{
Neneng Sofiyanti \\ R. Aditya Kristamtomo Putra \\ sofiyanz2909@gmail.com \\ Universitas Singaperbangsa Karawang
}

\begin{abstract}
The result of preliminary studies was found that Penyuluh Keluarga Berencana (PKB) Performance is not yet optimal. Of the many factors that cause is found, Career Development and work motivation is the most dominant factor of influence. Therefore the formulated problem include : how career development, work motivation, and Penyuluh Keluarga Berencana performance. How was significant on career development and work motivation to Penyuluh Keluarga Berencana performance at BKBPP Sub-Province of Karawang by partial and simultan.
\end{abstract}

The research of target is obtaining empiric evidence and finding clarity of phenomenon and also conclusion about the influence of career development and work motivation to Penyuluh Keluarga Berencana performance at BKBPP SubProvince of Karawang.

The research method used is descriptive survey and explanatory survey. The sampling technique was used sensus method. Data analysis techniques is to expose each variable we,it used range scale. Data analysis technique used correlation analysis technique variables and Path Analysis Technique, to expose the influence of career development and work motivation.

The conclusion from the examination that :

1. Career Development at BKBPP Sub-Province of Karawang is quite good.

2. Work Motivation at BKBPP Sub-Province of Karawang is high.

3. Performance of Penyuluh Keluarga Berencana at BKBPP Sub-Province of Karawang is quite high.

4. Career development Influence directly to Performance of Penyuluh Keluarga Berencana at BKBPP Sub-Province of Karawang

5. Work motivation Influence directly to Performance of Penyuluh Keluarga Berencana at BKBPP Sub-Province of Karawang.

6. career development and work motivation Simultaneously influence to Performance of Penyuluh Keluarga Berencana at BKBPP Sub-Province of Karawang.

Keywords : Career Development, Work Motivation, Performance of Penyuluh

41.

Jurnal Manajemen \& Bisnis Kreatif 


\section{Keluarga Berencana}

\section{PENDAHULUAN}

Tujuan utama dibentuknya pemerintahan tidak lain adalah untuk menjaga suatu sistem ketertiban, sehingga masyarakat bisa menjalani kehidupannya secara wajar. Pemerintah, pada hakekatnya adalah pelayanan kepada masyarakat. Pemerintahan tidaklah diadakan untuk melayani dirinya sendiri, tetapi untuk melayani masyarakat serta menciptakan kondisi yang memungkinkan setiap anggota masyarakat dapat mengembangkan kemampuan dan kretivitasnya demi mencapai kemajuan bersama. Peningkatan dan tuntutan masyarakat akan pelayanan publik yang efektif, efisien serta memuaskan dari pegawai pemerintah sebagai pelayan publik semakin populer. Hal ini terkait dengan perkembangan kebutuhan, keinginan dan harapan masyarakat yang terus bertambah dan semakin mutakhir.

Dalam rangka mewujudkan hal tersebut, perlu kiranya memperhatikan kualitas Sumber Daya Manusia (SDM) yang handal, terlatih, serta terampil dan peka terhadap tuntutan masyarakat. Hanya saja, untuk menghasilkan sumber daya manusia yang kinerjanya atau prestasi kerjanya tinggi seorang pegawai tidak hanya perlu memiliki keterampilan, tetapi ia juga harus memiliki keinginan dan kegairahan untuk berprestasi tinggi. Oleh karena itu perlu adanya profesionalisme dari para pegawai, bagaimana membuat yang potensial menjadi aktual. Pengelolaan sumber daya manusia, organisasi bisnis, dan instansi pemerintah yang dilandaskan pada pendekatan psikologis, organisasi, kebudayaan serta agama diharapkan mampu menciptakan sumber daya manusia yang unggul dan kompetitif.

Salah satu upaya yang dapat diakukan untuk meningkatkan kemampuan SDM atau pegawai adalah dengan menciptakan iklim yang yang dapat memotivasi pegawai untuk meningkatkan kinerja atau prestasi kerjanya. Pemahaman tentang kebutuhan atau keinginan para pegawai sangat diperlukan dalam hal ini. Salah satu kebutuhan atau keinginan dari setiap pegawai adalah mendapatkan kesempatan untuk meniti karir dengan baik. Pegawai termotivasi meningkatkan prestasi kerja salah satunya dikarenakan ada jaminan karir yang jelas. Artinya setiap pegawai yang memperlihatkan prestasi kerja yang baik, akan memperoleh kesempatan untuk meningkatkan karirnya dengan baik pula. Sebaliknya, pegawai yang kurang berprestasi tidak akan mendapat kesempatan peningkatan karir.

Sebagai Organisasi perangkat Daerah yang baru dibentuk berdasarkan Peraturan daerah Nomor 10 tahun 2008, Badan Keluarga Berencana dan Pemberdayaan Perempuan Kabupaten Karawang mempunyai tugas pokok membantu Bupati dalam melaksanakan sebagian kewenangan daerah di bidang Keluarga Berencana dan Pemberdayaan Perempuan serta tugas pembantuan yang ditugaskan kepada pemerintah daerah.

Penyelenggaraan kebijakan pembangunan di bidang Keluarga Berencana dan Pemberdayaan Perempuan merupakan salah satu bidang kewenangan yang diserahkan dan menjadi tanggung jawab daerah, hal ini sebagai implementasi dari Undang - undang nomor 32 Tahun 2004 tentang Pemerintahan Daerah. Masalah keluarga berencana dan pemberdayaan perempuan mempunyai permasalahan yang cukup complek, permasalahan tersebut disamping menjadi masalah nasional 
juga menjadi masalah Internasional, terutama masalah penduduk dan kompleksitasnya yang sulit dipecahkan. Tugas tersebut menjadi tanggung jawab Badan Keluaarga Berencana dan Pemberdayaan Perempuan Kabupaten Karawang.

Kondisi yang ada di wilayah Kabupaten Karawang dengan jumlah penduduk, luas wilayah, kondisi demografi dan banyaknya keluarga yang harus ditangani, menunjukan indikasi bahwa Badan Keluarga Berencana dan Pemberdayaan Keluarga Kabupaten Karawang menghadapi berbagai tantangan dan kendala, terutama yang timbul dari keterbatasan sumber daya manusia untuk melaksanakan tugas dan fungsi di berbagai tingkat administrasi. Keadaan ini jelas tergambar dari jumlah pegawai yang terdapat di Badan Keluarga Berencana dan Pemberdayaan Keluarga Kabupaten Karawang yang hanya 135 orang, diantaranya Petugas Lapangan Keluarga Berencana ( PLKB ) : 9, Penyuluh KB 66, Ka UPT Penyuluh KB 15, Kasubag TU 15, di tingkat Kabupaten sebanyak 30 (sumber BKBPP Kabupaten Karawang Tahun 2016). Satu orang PKB berbanding 5064 KK dan dikaitkan dengan upaya mewujudkan visi mewujudkan keluarga Kecil berkualitas tahun 2018, dibutuhkannya sosok pegawai dengan profesi PKB yang handal, handal dalam arti selain memiliki pengetahuan dan keterampilan dalam penyuluhan yang baik, juga memiliki dorongan dan semangat juang atau motivasi kerja yang baik. Dalam pelaksanaan tugas sehari-hari PKB berhadapan langsung dengan masyarakat, sebagai pengelola sekaligus sebagai pelaksana program KB di tingkat Desa. Sebagai pengelola PKB melaksanakan fungsi perencanaan, fungsi kooerdinasi dan penggerakan, fungsi pengawasan serta pengendalian infut dan out put program di desanya.

Dalam jangka pendek indikator yang digunakan untuk mengukur keberhasilan PKB adalah pencapaian target pasangan usia subur yang dapat dimotivasi menjadi peserta KB baru dan peserta KB aktif di desanya. Selanjutnya komulatif dari pencapaian target seluruh desa menjadi gambaran pencapaian target pengelolaan program KB tingkat Kecamatan dan kumulatif tingkat kecamatan menjadi gambaran untuk tingkat Kabupaten Karawang.

Pada saat ini yang terjadi di lingkungan Badan Keluarga Berencana dan Pemberdayaan Perempuan (BKBPP) Kabupaten Karawang, fenomena pengembangan karier yang ada dilingkungan Badan Keluarga Berencana dan Pemberdayaan Perempuan Kabupaten Karawang, prosedur pelaksanaan sesuai aturan diantaranya tepat waktu dalam kenaikan pangkat/golongan, kenaikan gaji berkala, serta adanya pengembangan karier Penyuluh Keluarga Berencana yaitu meningkatan Karier dari penyuluh Keluarga Berencana menjadi tenaga pejabat truktural sebanyak 30 orang yaitu 15 menjadi Kepala UPT Penyuluh KB ( eselon 4a) dan 15 orang menjadi Kasubag TU penyuluh KB (eselon 4b ). Selain itu permasalahan yang terjadi pada saat ini adalah adanya proteksi Kepala Wilayah/pimpinan dari PLKB/PKB kepada pegawai nya untuk tidak mengembangkan karir nya di luar/mutasi sehingga hal ini membatasi pengembangan karir pegawai yang bersangkutan, tidak adanya kejelasan tentang pengembangan karir yang di berikan lembaga untuk penyuluh $\mathrm{KB}$, dimana adanya kecenderungan yang mengisi jabatan-jabatan internal yang ada di ambil dari luar PKB selanjutnya adalah tidak adanya kejelasan untuk peningkatan karir di masa

43. 
yang akan datang, hal ini dikarenakan tidak adanya jenjang jabatan untuk penyuluh $\mathrm{KB}$.

Selain pengembangan karir faktor dominan lain yang mempengaruhi kinerja pegawai adalah motivasi kerja. Hasibuan dalam Nawawi (2006:64) menyatakan bahwa hasil kerja atau prestasi merupakan gabungan dari tiga faktor terdiri dari minat dalam bekerja, penerimaan delegasi tugas, dan tingkat motivasi seorang pekerja. Motivasi kerja yang tinggi merupakan penunjang bagi terwujudnya kinerja yang tinggi. Sebaliknya motivasi kerja yang rendah akan berdampak kinerja akan menjadi buruk.

Fenomena yang terjadi saat ini di lingkungan Badan Keluarga Berencana dan Pemberdayaan Perempuan (BKBPP) Kabupaten Karawang terkait motivasi kerja pegawai diantaranya adalah : masih banyak pegawai yang terlambat masuk kantor, mangkir/tidak masuk kerja,masih ada pegawai yang tidak memahami tugas, masih adanya pemberian penghargaan yang kurang tepat sasaran, pemerataan pegawai yang belum optimal. motivasi kerja Penyuluh Keluarga Berencana masih rendah.

Berdasarkan uraian di atas ,maka penulis tertarik untuk memilih, membahas masalah pengembangan karir, motivasi kerja yang ada diperusahaan pada saat ini, serta pengaruhnya terhadap kinerja pegawai secara umum.

\section{TINJAUAN PUSTAKA \\ Pengembangan Karier}

Karir merupakan perkembangan karyawan secara individual dalam jenjang jabatan atau kepangkatan yang dapat dicapai selama masa kerja tertentu dalam suatu organisasi.

Pengembangan karir sangat penting untuk suatu perusahaan atau organisasi, karena karir merupakan kebutuhan yang harus terus ditumbuhkan dalam diri seorang tenaga kerja, sehingga mampu mendorong kemauan kerjanya.pengembangan karir harus dilakukan melalui penumbuhan kebutuhan karir tenaga kerja, menciptakan kondisi dan kesempatan pengembangan karir serta melakukan penyesuaian antara keduanya. Pengembangan karir juga sangat membantu pegawai dalam menganalisis kemauan dan minat mereka untuk tumbuh lebih dapat disesuaikan dengan kebutuhan sumber daya manusia sejalan dengan pertumbuhan dan perkembangan lembaga.

Casio dalam Wahyudi (2002:162) mengatakan bahwa karir adalah "Rangkaian promosi jabatan atau mutasi jabatan yang lebih tinggi dalam jenjang hirarki yang dialami oleh seorang karyawan selama masa kerjanya."

Fubrin dalam Mangkunegara (2001:77) mendefinisikan "Pengembangan karir adalah aktifitas kepegawaian yang membantu pegawai-pegawai merencanakan karir masa depan mereka di perusahaan agar perusahaan dan pegawai yang bersangkutan dapat mengembangkan diri secara maksimum".

Dengan adanya program pengembangan pegawai merupakan kebutuhan yang mendasar, baik ditinjau dari segi organisasi maupun pegawainya yang bersangkutan. Bagi pegawai yang dinamis, kebutuhan pengembangan diri merupakan suatu dorongan untuk bekerja lebih giat dan lebih produktif, sehingga membawa pengaruh dalam prestasi kerja untuk selanjutnya oleh karena itu bagi

44. 
pegawai yang mengharapkan karier akan lebih baik dari pada pegawai yang tidak mengharapkan karier, maka dari itu pengembangan diri merupakan suatu jalan untuk mencapai cita-cita yang diinginkan dari dirinya sendiri maupun untuk perusahaannya.

\section{Motivasi Kerja}

Robert Heller dalam Wibowo (2010:378) menyatakan bahwa motivasi adalah keinginan untuk bertindak. Sedangkan Robbins dalam Wibowo (2010:378-379) menyatakan motivasi sebagai proses yang menyebabkan intensitas (intensity), arah (direction), dan usaha terus menerus (persistence) individu mencapai tujuan. Intensitas menunjukkan seberapa keras orang berusaha. Tetapi intensitas tinggi tidak mungkin mengarah pada hasil kinerja yang baik, kecuali usaha dilakukan dalam arah yang menguntungkan organisasi. Motivasi merupakan ukuran berapa lama seseorang dapat menjaga usaha mereka. Individu yang termotivasi akan menjalankan tugas cukup lama untuk mencapai tujuan mereka.

Menurut Uno (2009:3) istilah motivasi berasal dari kata motif yang dapat diartikan sebagai kekuatan yang terdapat dalam diri individu, yang menyebabkan individu tersebut bertindak atau berbuat.

Motif adalah daya penggerak dalam diri sesorang untuk melakukan aktifitas tertentu untuk mencapai tujuan tertentu. Dengan demikian motivasi merupakan dorongan yang terdapat dalam diri seseorang untuk berusaha mengadakan perubahan tingkah laku yang lebih baik dalam memenuhi kebutuhannya.

\section{Kinerja}

Kinerja menurut kamus umum bahasa Indonesia adalah asal kata dasar kerja mempunyai arti "perbuatan melakukan sesuatu" (Poerwadarminta, 2002:492).

Faustino Cardoso Gomes dalam Mangkunegara (2009:9) mengemukakan definisi kinerja sebagai : "ungkapan seperti output, efisiensi serta efektivitas sering dihubungkan dengan produktivitas".

Selanjutnya Mangkunegara (2009:9) menyatakan bahwa: "kinerja (prestasi kerja) adalah hasil kerja secara kualitas dan kuantitas yang dicapai oleh seseorang dalam melaksanakan tugasnya sesuai dengan tanggung jawab yang diberikan kepadanya".

Kinerja adalah tentang melakukan pekerjaan dan hasil yang dicapai dari pekerjaan tersebut. Kinerja adalah tentang apa yang dikerjakan dan bagaimana cara mengerjakannya. Kinerja merupakan hasil pekerjaan yang mempunyai hubungan kuat dengan tujuan strategis organisasi, kepuasan konsumen dan memberikan kontribusi ekonomi. (Armstrong dan Baron dalam Wibowo, 2010:2). Dengan demikian, kinerja adalah sesuatu hasil yang dicapai, prestasi yang diperlihatkan, kemampuan kerja pegawai dalam melaksanakan tugas sesuai dengan standar atau persyaratan pekerjaan yang telah ditetapkan sebelumnya.

\section{Kerangka Pemikiran}

Karir merupakan kebutuhan yang sangat penting bagi pegawai, sehingga organisasi harus memanfaatkan kebutuhan itu untuk memotivasi pegawai dengan mengijinkan pegawai mengambil keputusannya sendiri. Dengan adanya motivasi pengembangan karir yang tinggi dari pegawai akan semakin meningkatkan

45. 
motivasi kerja pegawai dalam rangka mempersiapkan diri untuk menghadapi pekerjaan yang lebih penting.

Applebaum et al, (2001) dan Cianni dan Wnuck (1997) menyatakan bahwa pegawai yang mempunyai kesempatan yang tinggi meningkatkan karirnya akan merangsang motivasinya untuk bekerja lebih baik. Pengembangan karir yang baik yang diraih pegawai maka kinerjanya akan meningkat atau dengan kata lain pengembangan karir berpengaruh signifikan terhadap kinerja.

Pengembangan karier dalam setiap organisasi sangat penting untuk regenerasi dari pegawai lama kepada pegawai yang disiapkan, untuk itu perlu pembinaan dengan memberi tanggung jawab yang lebih besar berdasarkan prestasi kerja. Menurut penilaian prestasi, selain hal itu beberapa hal yang perlu diperhatikan selain prestasi kerja adalah hubungan kerja dengan pimpinan, dengan bawahan dan mutu dari pekerjaan, pengembangan karier juga merupakan motivasi agar pegawai yang bekerja dapat terdorong untuk berprestasi sehingga kinerja pegawai akan meningkat.

Suherlan (2008) menyatakan bahwa terdapat hubungan yang positif signifikan antara pengembangan karir dan motivasi kerja terhadap kinerja karyawan. Hal ini menunjukkan bahwa semakin baik pengembangan karir dan semakin tinggi motivasi kerja maka akan semakin meningkatkan kinerja pegawai tersebut dan begitu juga sebaliknya.

Hasibuan dalam Nawawi (2006:64) menyatakan bahwa hasil kerja atau prestasi merupakan gabungan dari tiga faktor terdiri dari minat dalam bekerja, penerimaan delegasi tugas, dan tingkat motivasi seorang pekerja. Motivasi kerja yang tinggi merupakan penunjang bagi terwujudnya kinerja yang tinggi. Sebaliknya motivasi kerja yang rendah akan berdampak kinerja akan menjadi buruk.

Kinerja organisasi yang berwujud pelayanan yang berkualitas juga dipengaruhi oleh kapasitas individu. Tingginya motivasi kerja yang dirasakan pegawai sangat tergantung dari sudut pandang, kebutuhan, dan lingkungan seseorang yang mengalaminya. Dengan memberi kesempatan dan kebebasan pada pegawai untuk berekpresi namun bertanggung jawab dalam membuat rencanarancana program dengan menggunakan metode-metode yang ia kembangkan, akan mebuat pegawai merasa termotivasi dan bangga karena dihargai ide-idenya. Motivasi kerja pegawai yang tinggi menunjukan adanya keberhasilan terhadap pengelolaan organisasi. Motivasi mempunyai hubungan positif dengan produktivitas. Semakin kuat motivasi maka semakin tinggi produktivitasnya. Motivasi banyak dipengaruhi emosi. Seseorang yang memiliki motivasi tinggi akan selalu menerima kritik dan saran dari luar serta telah mempersiapkan diri secara matang dengan hal-hal yang akan terjadi dilapangan (Iskandar, 2002:2).

\section{METODE PENELITIAN}

Seperti yang terungkap di dalam identifikasi masalah penelitian, bahwa pokok masalah yang diteliti adalah Pengembangan karir $\left(\mathrm{X}_{1}\right)$, motivasi kerja $\left(\mathrm{X}_{2}\right)$ (sebagai variabel bebas) dan kinerja karyawan (Y) (sebagai variabel terikat).

Teknik sampling yang digunakan dalam penelitian ini adalah probability sampling, yaitu teknik sampling yang memberikan peluang yang sama bagi setiap unsur (anggota) populasi untuk dipilih sebagai sampel. Populasi penelitian yang

46. 
diteliti adalah penyuluh keluarga berencana (PKB) sebanyak 80 orang (sumber : BKPP, 2016).

Pengumpulan data dilakukan dengan cara penelitian lapangan (field research), melalui penyebaran kuesioner yang terstruktur.

\section{Metode Pengujian Instrumen}

Uji Validitas,

Validitas adalah suatu ukuran yang menunjukkan tingkat-tingkat kevalidan atau kesahihan suatu instrumen. Suatu instrumen yang valid valid atau sahih mempunyai validitas tinggi. Sebaliknya, instrumen yang kurang valid berarti memiliki validitas rendah (Arikunto, 2010:168).

Uji Reliabilitas

Reliabilitas adalah tingkat kemampuan suatu instrumen penelitian untuk dapat mengukur suatu variabel secara berulangkali dan mampu menghasilkan informasi atau data yang sama atau sedikit sekali bervariasi. Dengan kata lain instrumen tersebut mampu menunjukkan keakuratan, kestabilan dan konsistensi dalam menghasilkan data dari variabel yang diukur (Arikunto, 2010:171).

Uji normalitas digunakan dalam penelitian adalah untuk mengetahui apakah variabel dependen, independen atau keduanya berdistribusi normal, mendekati normal atau tidaknya dengan rumus :

$\mathrm{x}^{2}=\Sigma \frac{\mathrm{Oi}^{2}}{E i}-\mathrm{n}$

\section{Analisis Deskriftif}

Dalam menggambarkan keadaan pengembangan karir, motivasi kerja dan kinerja penyuluh keluarga berencana digunakan rentang skala. Adapun langkahlangkahnya adalah sebagai berikut :

1. Melihat tabulasi frekuensi

Hasil Jawaban kuisioner dari responden kemudian dimasukkan ke dalam tabel tabulasi frekuensi

2. Melihat rentang skala

Menentukan rentang skala dengan menggunakan rumus sebagai berikut :

$$
\begin{aligned}
& R S=\frac{\mathrm{n}(\mathrm{m}-1)}{\mathrm{m}} \\
& R S=\frac{80(5-1)}{5} \\
& =64 \\
& =1 \times 80 \\
& =80 \\
& =5 \times 80 \\
& =400
\end{aligned}
$$

Skala terendah $=$ skor terendah $\times$ jumlah sampel

Skala tertinggi $=$ skor tertinggi $x$ jumlah sampel

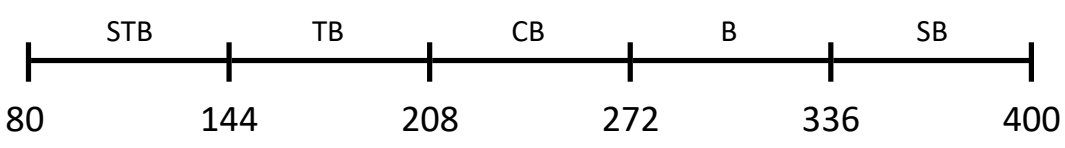

47. 


\section{Rentang Skala}

\section{Analisis Korelasi Produk Moment}

Dalam penelitian ini menggunakan Analisis korelasi produk moment (correlation product moment) adalah salah satu pendekatan untuk mengetahui keeratan antara satu variabel dengan variabel lainya, dengan rumus :

$$
\mathrm{r}=\frac{\mathrm{n} \Sigma \mathrm{XY}-\Sigma \mathrm{X} \Sigma \mathrm{Y}}{\sqrt{\left(\mathrm{n} \Sigma \mathrm{x}^{2}-(\Sigma \mathrm{X})^{2}\right)\left(\mathrm{n} \Sigma \mathrm{Y}^{2}-(\Sigma \mathrm{Y})^{2}\right)}}
$$

Dimana : $\mathrm{r}=$ Koefisien korelasi $\mathrm{x}=$ Variabel Independen

Sumber : Sugiyono (2010:212)

$$
\mathrm{n}=\text { Jumlah Sampel } \quad \mathrm{y}=\text { Variabel dependen }
$$

Dengan ketentuan : bila $r_{s}=+1$ atau mendekati 1 , maka korelasi antara kedua variabel dikatakan positif dan sangat kuat sekali bersifat searah. Bila $r_{s}=-1$, Maka korelasi kedua variabel versifat negatif sehingga kenaikan nilai-nilai Y yang sebaliknya. Pengujian signifikan korelasi dapat dihitung dengan uji t, dengan perhitungan rumus sebagai berikut :

$$
t=\frac{r \sqrt{n-2}}{\sqrt{1-r^{2}}}
$$

Sumber : Sugiyono $(2010: 214)$

selanjutnya digunakan distribusi t dengan $\mathrm{df}=(\mathrm{n}-2)$. Kriteria pengujian adalah olah Ho jika t yang dihitung lebih besar dari t tabel jika $t$ hitung lebih kecil dari $t$ tabel maka Ho diterima dan $\mathrm{H}_{1}$ ditolak.

Koefisien Determinasi $\left(\mathrm{R}^{2}\right)$

Analisis koefisien determinasi digunakan untuk menentukan besarnya variasi dari kinerja yang dapat diterangkan oleh variabel kepemimpinan dan motivasi kerja. Koefisien determinasi dilambangkan dengan $\mathrm{R}^{2}$ merupakan proporsi hubungan antara Y dengan X. Nilai koefisien determinasi adalah diantara 0 (nol) dan 1 (satu). Nilai $\mathrm{R}^{2}$ yang kecil berarti kemampuan variabel-variabel independen dalam menjelaskan variabel dependen amat kecil. Nilai yang mendekati 1 (satu) berarti variabel-variabel independen memberikan hampir semua informasi yang dibutuhkan untuk memprediksi variabel-variabel independen.

\section{Hasil Penelitian \\ Uji validitas}

Validitas adalah suatu ukuran yang menunjukkan tingkat-tingkat kevalidan suatu instrumen. Untuk menentukan valid atau tidaknya instrumen tersebut adalah dengan membandingkan hasil perhitungan korelasi dengan tabel harga kritis dan $r$ product moment pada taraf kepercayaan $95 \%$ atau taraf signifikan 5\%. Apabila hasil perhitungan $r$ hitung lebih besar dibanding dengan nilai yang ada pada $r$ kritis, maka instrumen dinyatakan sudah valid. Persyaratan minimum agar dapat dianggap valid apabila $r$ kritis $=0,3$.

48. 
Adapun hasil pengujian mengenai tingkat validitas ketiga variabel dalam stiap dimensi dan pernyataan pada kuisioner, dapat dilihat pada tabel sebagai berikut :

Tabel 4.5

Hasil Uji Validitas Variabel Pengembangan Karir $\left(\mathbf{X}_{\mathbf{1}}\right)$

\begin{tabular}{|c|c|c|c|}
\hline No. Pernyataan & r Hitung & r Kritis & Kriteria \\
\hline$X_{1}-1$ & 0,515 & 0,3 & Valid \\
\hline$X_{1}-2$ & 0,587 & 0,3 & Valid \\
\hline$X_{1}-3$ & 0,664 & 0,3 & Valid \\
\hline$X_{1}-4$ & 0,647 & 0,3 & Valid \\
\hline$X_{1}-5$ & 0,449 & 0,3 & Valid \\
\hline$X_{1}-6$ & 0,371 & 0,3 & Valid \\
\hline$X_{1}-7$ & 0,547 & 0,3 & Valid \\
\hline$X_{1}-8$ & 0,496 & 0,3 & Valid \\
\hline$X_{1}-9$ & 0,399 & 0,3 & Valid \\
\hline$X_{1}-10$ & 0,354 & 0,3 & Valid \\
\hline$X_{1}-11$ & 0,503 & 0,3 & Valid \\
\hline$X_{1}-12$ & 0,653 & 0,3 & Valid \\
\hline$X_{1}-13$ & 0,694 & 0,3 & Valid \\
\hline$X_{1}-14$ & 0,649 & 0,3 & Valid \\
\hline$X_{1}-15$ & 0,418 & 0,3 & Valid \\
\hline$X_{1}-16$ & 0,359 & 0,3 & Valid \\
\hline$X_{1}-17$ & 0,503 & 0,3 & Valid \\
\hline$X_{1}-18$ & 0,653 & 0,3 & Valid \\
\hline$X_{1}-19$ & 0,694 & 0,3 & Valid \\
\hline$X_{1}-20$ & 0,649 & 0,3 & Valid \\
\hline$X_{1}-8$ & 0,496 & 0,3 & Valid \\
\hline
\end{tabular}

Sumber : Hasil pengolahan data, 2017

Dari hasil uji validitas variabel Pengembangan Karir, sebanyak 20 pernyataan kuisioner dinyatakan valid.

Tabel 4.6

Hasil Uji Validitas Variabel Motivasi Kerja $\left(\mathbf{X}_{2}\right)$

\begin{tabular}{|c|c|c|c|}
\hline No. Pernyataan & r Hitung & r Kritis & Kriteria \\
\hline$X_{2}-1$ & 0,722 & 0,3 & Valid \\
\hline$X_{2}-2$ & 0,514 & 0,3 & Valid \\
\hline$X_{2}-3$ & 0,490 & 0,3 & Valid \\
\hline$X_{2}-4$ & 0,551 & 0,3 & Valid \\
\hline$X_{2}-5$ & 0,581 & 0,3 & Valid \\
\hline$X_{2}-6$ & 0,611 & 0,3 & Valid \\
\hline$X_{2}-7$ & 0,621 & 0,3 & Valid \\
\hline
\end{tabular}

49. 


\begin{tabular}{|c|c|c|c|}
\hline$X_{2}-8$ & 0,465 & 0,3 & Valid \\
\hline$X_{2}-9$ & 0,410 & 0,3 & Valid \\
\hline$X_{2}-10$ & 0,673 & 0,3 & Valid \\
\hline
\end{tabular}

Tabel 4.7

Hasil Uji Validitas Variabel Motivasi Kerja ( $\left.\mathbf{X}_{2}\right)$ (lanjutan)

\begin{tabular}{|c|c|c|c|}
\hline $\mathrm{X}_{2}-11$ & 0,591 & 0,3 & Valid \\
\hline $\mathrm{X}_{2}-12$ & 0,469 & 0,3 & Valid \\
\hline $\mathrm{X}_{2}-13$ & 0,722 & 0,3 & Valid \\
\hline $\mathrm{X}_{2}-14$ & 0,514 & 0,3 & Valid \\
\hline $\mathrm{X}_{2}-15$ & 0,490 & 0,3 & Valid \\
\hline $\mathrm{X}_{2}-16$ & 0,551 & 0,3 & Valid \\
\hline $\mathrm{X}_{2}-17$ & 0,581 & 0,3 & Valid \\
\hline $\mathrm{X}_{2}-18$ & 0,611 & 0,3 & Valid \\
\hline $\mathrm{X}_{2}-19$ & 0,621 & 0,3 & Valid \\
\hline $\mathrm{X}_{2}-20$ & 0,465 & 0,3 & Valid \\
\hline
\end{tabular}

Sumber : Hasil pengolahan data, 2017

Dari hasil uji validitas variabel motivasi kerja, sebanyak 20 pernyataan kuisioner dinyatakan valid.

Tabel 4.8

Hasil Uji Validitas Variabel Kinerja Penyuluh Keluarga Berencana (Y)

\begin{tabular}{|c|c|c|c|}
\hline No. Pernyataan & r Hitung & r Kritis & Kriteria \\
\hline $\mathrm{Y}-1$ & 0,470 & 0,3 & Valid \\
\hline $\mathrm{Y}-2$ & 0,559 & 0,3 & Valid \\
\hline $\mathrm{Y}-3$ & 0,611 & 0,3 & Valid \\
\hline $\mathrm{Y}-4$ & 0,400 & 0,3 & Valid \\
\hline $\mathrm{Y}-5$ & 0,475 & 0,3 & Valid \\
\hline $\mathrm{Y}-6$ & 0,422 & 0,3 & Valid \\
\hline $\mathrm{Y}-7$ & 0,487 & 0,3 & Valid \\
\hline $\mathrm{Y}-8$ & 0,574 & 0,3 & Valid \\
\hline $\mathrm{Y}-9$ & 0,539 & 0,3 & Valid \\
\hline $\mathrm{Y}-10$ & 0,392 & 0,3 & Valid \\
\hline $\mathrm{Y}-11$ & 0,538 & 0,3 & Valid \\
\hline $\mathrm{Y}-12$ & 0,581 & 0,3 & Valid \\
\hline $\mathrm{Y}-13$ & 0,625 & 0,3 & Valid \\
\hline $\mathrm{Y}-14$ & 0,426 & 0,3 & Valid \\
\hline $\mathrm{Y}-15$ & 0,430 & 0,3 & Valid \\
\hline
\end{tabular}

Sumber : Hasil Pengolahan Data, 2017

50.

Jurnal Manajemen \& Bisnis Kreatif 
Beradasarkan tabel 4.9 diatas, diketahui bahwa 15 pernyataan kuisioner dinyatakan valid.

\section{Uji Reliabilitas}

Teknik pengujian reliabilitas menggunakan koefisien alpha cronbach dengan taraf nyata 5\% (0,05). Untuk menilai reliabel tidaknya instrumen dilakukan dengan mengkonsultasikan hasil perhitungan alpha cronbach dengan angka tabel $\mathrm{r}$ hitung. apabila cronbach Alpha $(\alpha)>0,6$ maka reliabilitas pertanyaan bisa diterima.

Reliabilitas untuk kuisioner masing-masing variabel dapat dapat dilihat pada tabel sebagai berikut :

Tabel 4.10

Hasil Uji Reliabilitas

\begin{tabular}{|c|c|c|c|}
\hline Variabel & r Hitung & r Kritis & Kriteria \\
\hline Pengembangan karir $\left(\mathrm{X}_{1}\right)$ & 0,904 & 0,6 & Reliabel \\
\hline Motivasi Kerja $\left(\mathrm{X}_{2}\right)$ & 0,913 & 0,6 & Reliabel \\
\hline Kinerja Penyuluh Keluarga & 0,863 & 0,6 & Reliabel \\
\hline
\end{tabular}

Sumber : Hasil pengujian data, 2017

Dari hasil uji reliabilitas tersebut diatas pada tabel 4.8, diketahui bahwa untuk setiap variabel $(\alpha)>0,6$, sehingga variabel Pengembangan karir, variabel motivasi kerja dan variabel Kinerja Penyuluh Keluarga Berencana (PKB). dinyatakan reliabel.

\section{Uji Normalitas}

Uji normalitas digunakan untuk mengetahui apakah suatu data mengikuti sebaran normal atau tidak, untuk mengetahui apakah data tersebut mengikuti sebaran normal dapat dilakukan dengan berbagai metode, diantaranya metode Kolmogorov-Smirnov. Hasil perhitungan data menunjukkan bahwa semua variabel mengikuti distribusi normal dengan $p$-value $>\alpha$ (Sudjana, 2005: 273), yang dijelaskan pada tabel berikut:

Tabel 4.11

Uji Normalitas Instrumen

\begin{tabular}{|c|c|c|c|}
\hline \multirow[t]{2}{*}{ Variabel } & \multicolumn{2}{|c|}{$\begin{array}{l}\text { Kolmogorov- } \\
\text { Smirnov }\end{array}$} & \multirow[t]{2}{*}{ Kesimpulan } \\
\hline & p-value & $\mathbf{A}$ & \\
\hline Pengembangan karir $\left(\mathrm{X}_{1}\right)$ & 1,129 & \multirow{3}{*}{0,05} & Dist. Normal \\
\hline Motivasi Kerja $\left(\mathrm{X}_{2}\right)$ & 0,942 & & Dist. Normal \\
\hline $\begin{array}{l}\text { Kinerja Penyuluh Keluarga } \\
\text { Berencana (PKB). (Y) }\end{array}$ & 0,811 & & Dist. Normal \\
\hline
\end{tabular}

Sumber : Hasil Pengolahan Data, 2017

51. 
Tabel di atas menunjukkan bahwa semua variabel mengikuti sebaran data normal karena nilai $\mathrm{p}$-value $>0,05$.

\section{Rekapitulasi Variabel Pengembangan Karir}

Berdasarkan pendapat responden dari masing-masing item selanjutnya dibuat rekapitulasi variabel motivasi. Variabel ini berada dalam kriteria cukup baik seperti terlihat pada gambar di bawah ini :

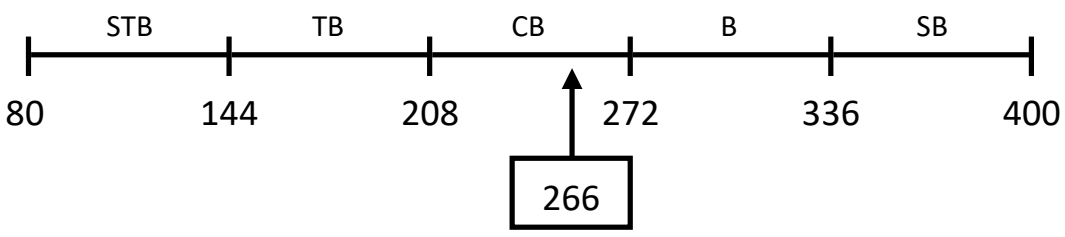

Gambar 4.1

Rentang Skala Pengembangan Karir $\left(\mathbf{X}_{1}\right)$

Hal ini menunjukkan bahwa pengembangan karir $\left(\mathrm{X}_{1}\right)$ pada Badan Keluarga Berencana dan Pemberdayaan Perempuan Kabupaten Karawang secara umum berada pada kriteria cukup baik.

\section{Rekapitulasi Variabel Motivasi Kerja}

Berdasarkan pendapat responden dari masing-masing item selanjutnya dibuat rekapitulasi variabel motivasi seperti yang ditampilkan variabel ini berada dalam kriteria tinggi seperti terlihat pada gambar di bawah ini :

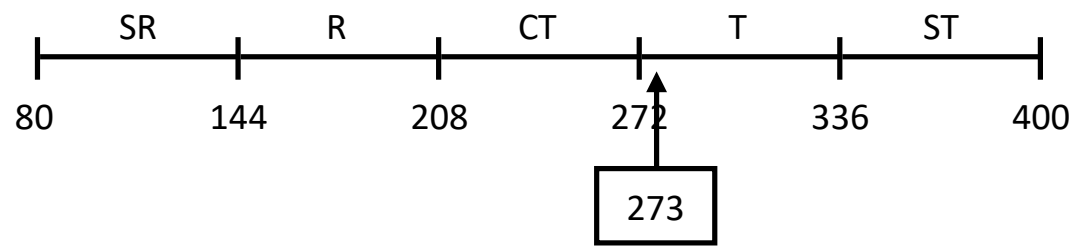

Gambar 4.2

Rentang Skala Motivasi Kerja $\left(\mathbf{X}_{2}\right)$

Hal ini menunjukkan bahwa motivasi kerja pada Badan Keluarga Berencana dan Pemberdayaan Perempuan Kabupaten Karawang secara umum berada pada kriteria tinggi.

\section{Rekapitulasi Variabel Kinerja Penyuluh Keluarga Berencana (PKB)}

Berdasarkan pendapat responden dari masing-masing item selanjutnya dibuat rekapitulasi variabel kinerja pegawai seperti variabel ini berada dalam kriteria cukup tinggi seperti terlihat pada gambar di bawah ini :

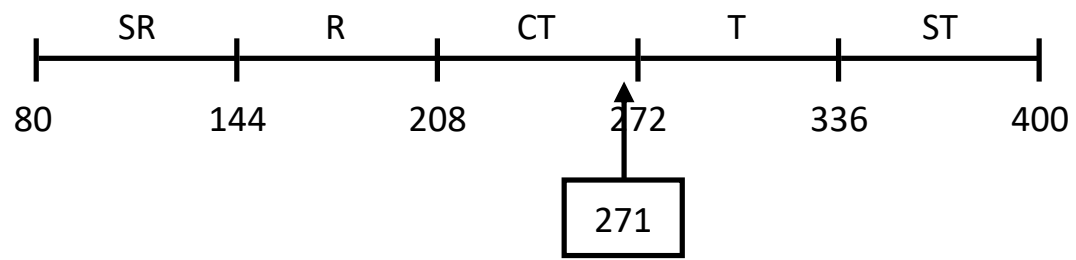

52. Jurnal Manajemen \& Bisnis Kreatif 


\section{Rentang Skala Kinerja Karyawan (Y)}

Hal ini menunjukkan bahwa Kinerja Penyuluh Keluarga Berencana (PKB) pada Badan Keluarga Berencana dan Pemberdayaan Perempuan Kabupaten Karawang secara umum berada pada kondisi cukup tinggi.

\section{Besaran Hubungan Antara Variabel Bebas}

Tabel 4.15 menunjukkan bahwa hasil perhitungan korelasi dengan model 2tailed atau dua sisi diperoleh hubungan antara variabel motivasi dengan kepuasan kerja sebesar 0,811 .

Tabel 4.15

Korelasi Bi-Variate

\begin{tabular}{|c|c|c|c|}
\hline & & $\begin{array}{c}\text { pengembangan } \\
\text { karir }\end{array}$ & Motivasi kerja \\
\hline \multirow[t]{2}{*}{$\begin{array}{c}\text { pengembangan } \\
\text { karir }\end{array}$} & $\begin{array}{c}\text { Pearson } \\
\text { Correlation } \\
\text { Sig. }(2 \text {-tailed })\end{array}$ & 1 & $\begin{array}{r}, 811\left({ }^{* *}\right) \\
000\end{array}$ \\
\hline & $\mathrm{N}$ & 80 & 80 \\
\hline \multirow[t]{2}{*}{ Motivasi kerja } & $\begin{array}{l}\text { Pearson } \\
\text { Correlation }\end{array}$ &, $811\left({ }^{* *}\right)$ & 1 \\
\hline & $\mathrm{N}$ & 80 & 80 \\
\hline
\end{tabular}

\section{Koefisien Jalur Pengembangan Karir $\left(\mathrm{X}_{1}\right)$ terhadap Kinerja Karyawan (Y)}

koefisien jalur untuk variabel pengembangan karir $\left(\mathrm{X}_{1}\right)$ terhadap variabel kinerja Penyuluh Keluarga Berencana (Y). Pada tabel tersebut menunjukkan pengaruh langsung variabel pengembangan karir $\left(\mathrm{X}_{1}\right)$ terhadap variabel kinerja Penyuluh Keluarga Berencana (Y) yaitu sebesar 0,706 sehingga diperoleh persamaan $\mathbf{Y}=\mathbf{0 , 7 0 6} \mathbf{X}_{\mathbf{1}}$

\section{Koefisien Jalur Motivasi Kerja $\left(\mathbf{X}_{2}\right)$ terhadap Kinerja Karyawan (Y)}

koefisien jalur untuk variabel motivasi kerja $\left(\mathrm{X}_{2}\right)$ terhadap variabel kinerja Penyuluh Keluarga Berencana (Y). Pada tabel tersebut menunjukkan pengaruh langsung variabel motivasi kerja $\left(\mathrm{X}_{2}\right)$ terhadap variabel kinerja Penyuluh Keluarga Berencana (PKB). (Y) yaitu sebesar 0,288 sehingga diperoleh persamaan $\mathbf{Y}=\mathbf{0 , 2 8 8} \mathbf{X}_{\mathbf{2}}$

\section{Pengaruh Bersamaan Variabel X Terhadap Variabel Y.}

Pengaruh langsung dan tidak langsung secara simultan dari variabel pengembangan karir $\left(\mathrm{X}_{1}\right)$ dan motivasi kerja $\left(\mathrm{X}_{2}\right)$ terhadap kinerja pegawai $(\mathrm{Y})$ variabel pengembangan karir mempunyai pengaruh langsung terhadap variabel kinerja pegawai sebesar 49,84\%, pengaruh tidak langsung melalui hubungannya dengan variabel kinerja pegawai sebesar $16,49 \%$. Sedangkan variabel motivasi kerja mempunyai pengaruh langsung terhadap variabel kinerja karyawan sebesar 
$8,29 \%$, pengaruh tidak langsung melalui hubungannya dengan variabel kinerja pegawai sebesar $16,49 \%$. Total pengaruh dari variabel bebas : pengembangan karir $\left(\mathrm{X}_{1}\right)$ dan motivasi kerja $\left(\mathrm{X}_{2}\right)$ terhadap kinerja pegawai $(\mathrm{Y})$ dinyatakan oleh besaran koefisien determinasi $\left(\mathrm{R}_{\mathrm{YX}}\right)^{2}$ sebesar $91,11 \%$. Efek dari faktor lain terhadap kinerja pegawai sebesar $8,89 \%$.

\section{DAFTAR PUSTAKA}

Arikunto, Suharsimi. 2010. Prosedur Penelitian. Jakarta : Rineka Cipta

Cascio, Wayne F, 2003, Managing Human Resources, Quality of Work Life, Profits, Mc. Graw-Hill Inc., New York.

Hariyanto, Sugeng. 2011. Pengaruh Pengembangan Karir terhadap Kinerja Karyawan (Studi pada Karyawan Bagian Asisten Manajer Distribusi dan SDM \& ADM PT PLN (Persero) Area Pelayanan dan Jaringan Malang) Tesis. Program Pascasarjana Magister Manajemen. Universitas Brawijaya.

Hasibuan, Malayu, S.P. 2008. Manajemen Sumber daya Manusia. Cetakan ke-11. Jakarta: PT. Bumi Aksara.

Herlan Suherlan MM. 2008. Jurnal Pariwisata-STP Bandung. Pengaruh Program Pengembangan Karir dan Motivasi Kerja Terhadap Kinerja Karyawan.

Mangkunegara. 2011. Manajemen Sumber Daya Manusia. Bandung: PT.Remaja Rosda Karya

Mangkunegara, Anwar. P. 2010. Manajemen Sumber daya Manusia Perusahaan. (cetakan ke-9). Bandung: PT. Remaja Rosda Karya Offset.

Mangkunegara, Anwar. P. 2010. Evaluasi Kinerja SDM. Cetakan keempat. Bandung: PT. Refika Aditama

Nawawi, H., 2006.Evaluasi dan Manajemen Kinerja di Lingkungan Perusahaan dan Industri.(cetakan ke-1). Yogyakarta: Gadjah Mada University Press

Riduwan dan Kuncoro, Engkos Achmad. 2008. Cara Menggunakan dan Memaknai Analisis Jalur (Path Analysis). Cetakan Kedua. Bandung: Alfabeta.

Samsudin, Sadili, 2005, Manajemen Sumber Daya Manusia, Cetakan Kesatu. Penerbit Pustaka Setia, Bandung

Sedarmayanti. 2010. Manajemen Sumber Daya Manusia Reformasi Birokrasi dan Manajemen Pegawai Negeri Sipil.Cetakan keempat. Bandung : PT. Refika Aditama

54.

Jurnal Manajemen \& Bisnis Kreatif 
Siagian, Sondang. 2009. Kiat Meningkatkan Produktivitas Kerja. Jakarta: PT. Rineka Cipta.

Sugiyono, 2010, Metode Penelitian Administrasi, Bandung: Alfabeta

Uno, H.B. 2009. Teori Motivasi dan Pengukurannya. Cetakan kelima. Jakarta: Bumi Aksara.

Wibowo, Felicia D. 2006. Analisis Pengaruh Peran Kepemimpinan dan Pengembangan Karir terhadap Komitmen Organisasi dalam Meningkatkan Kinerja Karyawan (Studi Kasus: PT. Bank Maspion Indonesia Cabang Semarang). Tesis. Program Pascasarjana Magister Manajemen. Universitas Diponegoro Semarang.

Wibowo. 2010. Manajemen Kinerja Cetakan ketiga.. Jakarta: PT. Raja Grafindo Perkasa 